o

${ }^{1}$ Faculty of Law, University of Ottawa, Ottawa, Canada

${ }^{2}$ Faculty of Medicine, University of Ottawa, Ottawa, Canada

${ }^{3}$ Ottawa Aesculapian Society, University of Ottawa, Ottawa, Canada

\section{Correspondence to} Professor Amir Attaran, Institute of Population Health, One Stewart Street, Ottawa, ON K1N 6N5, Canada; aattaran@uottawa.ca

Accepted 22 December 2010 Published Online First 30 January 2011

\title{
For peace and pain: the medical legitimisation of Afghanistan's poppy crop
}

\author{
Amir Attaran, ${ }^{1,2,3}$ Andrew Boozary ${ }^{3}$
}

\section{ABSTRACT}

Since the overthrow of the Taliban in 2001, there has been an overall increase in illicit opium production in Afghanistan and mounting human losses. The United Nations has attributed 1 million human deaths to Afghan opiates over the past decade. As the war in Afghanistan nears a crucial mark, the NATO coalition forces and Afghan people can no longer afford the same ineffective counternarcotics strategy. This commentary proposes a strategic revision that reframes Afghanistan's poppy problem as an opportunity for global public health. Specifically, The Afghan poppy crop could be repurposed away from illicit drug production, and towards manufacturing licit opioid analgesics to address unmet needs for pain palliation, particularly for diseases such as HIV/AIDS and cancer in the developing world - that is, illegal opium could be converted into legal pain medicine, solving two problems at once. We present a supply-anddemand that illustrates how this useful exchange could be made, and discuss the political opposition that now stands in the way and perpetuates the unsatisfactory status quo in Afghanistan.

\section{INTRODUCTION}

"Corruption and drug trafficking feed upon each other and undermine any development effort in Afghanistan."-Yury Fedotov's, Executive Director United Nations, Office on Drugs and Crime

War, population health and illicit drugs can be diabolically linked. Yet diplomacy often fails to view them as such, and irrationally imbues antidrug efforts with wishful thinking. Scholars cite the 'disaster' of a United Nations drug summit in 1998 that set the goal of 'eliminating or significantly reducing' the production of opium, cocaine and cannabis within a decade, and which boldly predicted a 'drug-free world' by last year. ${ }^{1}{ }^{2}$ Nowhere did that goal fail more spectacularly than in Afghanistan, where opium production has increased 40-fold since 2001. The global health implications of Afghanistan's drug trade are tremendous: 100000 deaths per year, 15 million drug addicts, and contagion of communicable disease at exorbitant rates. ${ }^{3}$ So, too, are the security implications: the Taliban taxes an opioid trade worth about $\$ 4$ billion in Afghanistan, as Al-Qaida takes its share of the $\$ 1$ billion export trade in Pakistan. ${ }^{3}$

With the ongoing commitment of over 140000 coalition troops in Afghanistan and shifting definitions of mission success, there is one last chance for NATO countries to re-evaluate the failed counternarcotics efforts and to pursue an evidence- based approach. This paper argues for a revised counternarcotics strategy in Afghanistan-one which links public health and counterinsurgency goals. Specifically, rather than let Afghanistan's poppy crop be trafficked by the Taliban to produce illicit heroin-a lucrative, illegal business that finances the war and terrorism-the crop should be repurposed and used to manufacture legal and clinically necessary palliative pain medicines such as codeine and morphine. By decoupling Afghanistan's opium poppy crop from illicit drug manufacture, and recoupling it to licit medicine manufacture, one both thwarts the insurgents' ambitions and improves medical care for some of the world's least fortunate patients.

\section{POPPY, WAR AND POLITICS}

Since the 2001 overthrow of the Taliban, opium poppy (Papaver somniferum) cultivation has increased dramatically: Afghanistan now produces $90 \%$ of the world's opium. Even with the 'surge' of American and NATO soldiers, the most recent (2010) report of the United Nations Office on Drugs and Crime (UNODC) highlights no decline in total opium cultivation-except that a crop disease caused a major decline (48\%) where military intervention could not. ${ }^{4}$ Even the crop failure, however, is bad news, because with scarcity the price of dry opium has risen vertiginously: up 164\% since 2009, offering a greater financial incentive for more drug trafficking in the Afghanistan-Pakistan region, and a heightened threat of insecurity. The 2010 data perfectly confirm a true but ignored conclusion that UNODC reached 2 years ago: that poppy eradication has been 'ineffective in terms of results,' and that a different comprehensive strategy is needed to address the opium threat. ${ }^{5}$

The failure of the counternarcotics strategy rests on a peculiar dynamic. While nominally enemies, actually both Taliban warlords and corrupt Afghan government officials are engaged in and financially enriched by illicit drug exports. This shared business interest means that neither side earnestly aims to end the trade or the state of war in which it thrives. On the contrary, when both Taliban warlords and corrupt officials earn drug wealth, both have an incentive to keep Afghanistan at war and lawless-the better to self-enrich. The result is not development or stability, but a huge movement of Afghanistan's wealth overseas, by both sides, ensuring future instability. As the American Ambassador to Afghanistan wrote in a secret diplomatic memo: 'Drug traffickers [and] corrupt officials ... do not benefit from keeping millions of dollars in Afghanistan and instead are motivated ... to move value into accounts and investments 
outside of Afghanistan. ${ }^{6}$ High officials, allegedly including Afghanistan's vice president, have been caught in drug investigations exporting tens of millions of dollars in cash. ${ }^{6}$

In this environment, attempts to eradicate poppy have only transient success, even when western force is applied. With the certainty that force cannot be applied forever, and that insurgents and officials can always collude to find a way around it, the eradication approach must be discarded. Instead, one must repurpose opium poppy cultivation away from the illicit drugs trade, and enfranchise Afghan opium farmers through legitimate production.

\section{MEDICAL DEMAND AND SUFFERING}

Opium is the raw material of both illicit drugs and licit pain medicines. An examination of global disease trends and the global pain medicine supply demonstrates a vast, unmet need for pain medicines in palliative care that could be met using repurposed Afghan poppy. The WHO Model List of Essential Medicines contains several recommended opioid analgesics, such as morphine and codeine, which are inexpensive to manufacture. However, those medicines are often unavailable to patients, because of a highly inequitable, legally binding quota system operated by the United Nations' International Narcotics Control Board (INCB).

Under current INCB rules, rich countries receive sufficient quotas of medical analgesics, while poor countries receive grossly inadequate quotas relative to their clinical needs. In 2007, North American and European populations alone consumed $92 \%$ of the world's morphine supply, while the remaining $8 \%$ of morphine was shared among $80 \%$ of humanity. ${ }^{7}$ INCB quotas are extremely inequitable: the quota for morphine is $10 \mathrm{~kg}$ in Nigeria (population 130 million) versus $5200 \mathrm{~kg}$ in Belgium (population 10.5 million) - a 6000-fold difference per capita. ${ }^{8}$

Currently, the WHO estimates that 6.2 million cancer and HIV/AIDS patients experience moderate or severe pain annually, because they do not receive opioid analgesia. Meeting these patients' analgesic needs is, however, impossible because INCB's legally binding quotas make opioid medicines scarce-and thus expensive. ${ }^{910}$ Because of INCB quotas, analgesics often cost more in developing countries than in developed countries. ${ }^{11}{ }^{12}$ Unless pain palliation is to be a 'rich man's right,' INCB must ease its inequitable quotas-which in turn means augmenting the global supply of opioid analgesics to satisfy unmet demand.

Afghanistan's poppy crop is indispensable to this objective. Opium can be extracted to produce morphine at a conservative ratio of 10:1, and morphine in turn can be synthesised into other medical analgesics (eg, codeine or dihydromorphine) with little loss. ${ }^{13}$ As such, Afghanistan's available poppy crop is sufficient to supply about 690 tons of morphine: enough to nearly triple the current global supply of that medicine, and to narrow substantially the analgesia gap between rich- and poor-country patients having terminal cancer or HIV/AIDS pain. No other country comes remotely close to producing enough. As such, the 'problem' of Afghanistan's opium poppy, which is now wasted on manufacturing illicit drugs, is potentially the solution for millions of suffering pain patients, who desperately need proper analgesic medicines.

\section{VESTED OPPOSITION}

If repurposing Afghanistan's opium poppy crop from illicit and dangerous drugs to licit and proper medicines could both temper the war and provide relief for patients in severe pain, why has it not been done?
Currently, a few countries dominate and profit from the licit opioid market. India produces over $90 \%$ of the world's licit opium, while Australia, China, France, Hungary, Spain, Turkey and the UK produce over $95 \%$ of the world's licit poppy straw (the non-flowering parts of the plant). ${ }^{14}$ Afghanistan's fresh opium is priced similarly to these competitors (\$48/ $\mathrm{kg}$ in 2010), but cannot compete because of discriminatory, arguably illegal trade barriers that favour the already-established countries. ${ }^{15}$ One such barrier is the '80:20 rule,' under which India and Turkey claim the right to supply $80 \%$ of the world's licit opium exports. ${ }^{16}$ United States law requires that at least $80 \%$ of imports be from India and Turkey, with the balance split among other long-established countries. ${ }^{17} 18$

Legally frozen out of the American market-the largest in the world-Afghan farmers cannot possibly build a legitimate opioid industry, so turn to illicit drug production. In denying them that option, current policy fosters drug addiction, enriches the Taliban, corrupts the Afghan government and intensifies a dangerous international war.

\section{NEXT STEPS}

The latest American and NATO efforts in Afghanistan seek to transcend traditional military measures, and to shift Afghans' perceptions by providing social and economic programmes. ${ }^{19}$ Accordingly, development aid and military tactics ought to shift away from the failed counternarcotics strategy of poppy eradication, and towards investment in pilot projects for cultivating and exporting licit poppy for use in pain medicines. To do this effectively, the Afghan government must enact laws that license poppy cultivation in secure areas, and Afghan and international military forces must protect those areas while the new economy builds itself. Traditional local Afghan leadership councils (shuras) could be called on to manage licensing and cultivation cooperatively, with collective responsibility if licenses are violated. ${ }^{20} \mathrm{~A}$ similar approach to licensing and collective responsibility has kept India's opium poppy cultivation in check for several decades with minimal diversion into illicit sale. ${ }^{21}$

At the international level, different United Nations agencies, specifically WHO and INCB, must stop acting at odds, and concertedly scale-up the production and clinical use of opioid analgesics on the Model List of Essential Medicines. This requires brokering supply agreements between poppy farming co-operatives and generic pharmaceutical manufacturers, and establishing detailed clinical practice guidelines for pain palliation in low- and middle-income countries. To ensure that WHO's pain palliation objectives are not sabotaged, the INCB will need to relax its inequitable quotas and champion the abolition of unfair trade barriers (perhaps with World Trade Organization assistance) that give a certain few countries a stranglehold on the global morphine market.

These ideas are not altogether new, but it is past time they be tried. Already the World Medical Association, the International Council on Security and Development, the European PARLIAMENT and national parliaments or their relevant committees in Canada, Italy, and Portugal have called for pilot projects. Those pilot projects have not gone head because of sophisticated opposition from corrupt Afghan officials, antinarcotics contractors, defence-establishment academics, and others who are vested in the status quo. ${ }^{22}$ There is, to be sure, a risk that the pilot projects will fail. But with the Afghanistan war entering its tenth year and becoming a dangerous quagmire, failure to try evidencebased alternatives could prove catastrophic. 


\section{Competing interests None.}

Provenance and peer review Commissioned; externally peer reviewed.

\section{REFERENCES}

1. Jelsma M. Drugs in the UN system: the unwritten history of the 1998 United Nations General Assembly Special Session on drugs. Int J Drug Policy 2003;14:181-95.

2. Wood E, Werb D, Marshall BD, et al. The war on drugs: a devastating public-policy disaster. Lancet 2009;373:989-90.

3. United Nations Office on Drugs and Crime. Addiction, Crime and Insurgency: The Transnational Threat of Afghan Opium. 2009.

4. United Nations Office on Drugs and Crime. Afghanistan Opium Survey 2010. 2010.

5. United Nations Office on Drugs and Crime. Afghanistan Opium Survey 2008. 2010.

6. Eikenberry K. Afghanistan: Capital Flight and its Impact on Future Stability. http://www. guardian.co.uk/world/us-embassy-cables-documents/230265 (accessed 19 0ct 2009).

7. International Narcotics Control Board. Estimated World Requirements for 2009 , Statistics for 2007 (accessed 7 Mar 2009).

8. Scholten W, Nygren-Krug H, Zucker HA. The World Health Organization paves the way for action to free people from the shackles of pain. Anesth Analg 2007;105:1-4.

9. Daut RI, Cleeland CS. The prevalence and severity of pain in cancer. Cancer 1982;50:1913-18

10. Breitbart W. Pain. In: O'Neill JF, Selwyn P, Schietinger H, eds. A Clinical Guide to Supportive and Palliative Care for HIVIAIDS. Washington, DC: Health Resources and Services Administration, 2003:85-122.
11. De Lima L, Sweeney C, Palmer JL, et al. Potent analgesics are more expensive for patients in developing countries: a comparative study. J Pain Palliati Care Pharmacother 2004;18:59-70.

12. De Lima L. Opioid availability in Latin America as a global problem: a new strategy with regional and national effects. J Palliat Med 2004;7:97-103.

13. Sanderson K. Opiates for the masses. Nature 2007:449:268-9.

14. INCB. Comments on the Reported Statistics on Narcotic Drugs 2009. http://www. incb.org/pdf/technical-reports/narcotic-drugs/2009/en_comments.pdf laccessed 10 Jun 2010).

15. United Nations Office on Drugs and Crime. Afghanistan Opium Survey 2010. 2010.

16. Jelsma M. Learning lessons from the Taliban opium ban. Int J Drug Policy 2005; 16:98-103

17. Mansfield D. An Analysis of Licit Opium Poppy Cultivation: India and Turkey. http:// www.davidmansfield.org/data/Policy Advice/UK/India-Turkeycultivation.doc (accessed 5 Oct 2010).

18. United States Code of Federal Regulations, 21 CFR 1312.13 (f) and (g).

19. Shanker T. Afghan push went beyond traditional military goals. New York Times 19 February 2010.

20. Biddle S, Christia F, Their A. Defining success in Afghanistan. Foreign Affairs August 2010. http://www.foreignaffairs.com/articles/66450/stephen-biddle-fotini-christiaand-j-alexander-thier/defining-success-in-afghanistan (accessed 21 Jan 2011).

21. Bhattacharii R. Case Study: India's Experiences in Licensing Poppy Cultivation for the Production of Medicines - Lessons for Afghanistan. 2007. http://www.icosgroup. net/documents/india case study.pdf.

22. Malloch-Brown M. Opium production in Afghanistan. BMJ 2008;336:972.

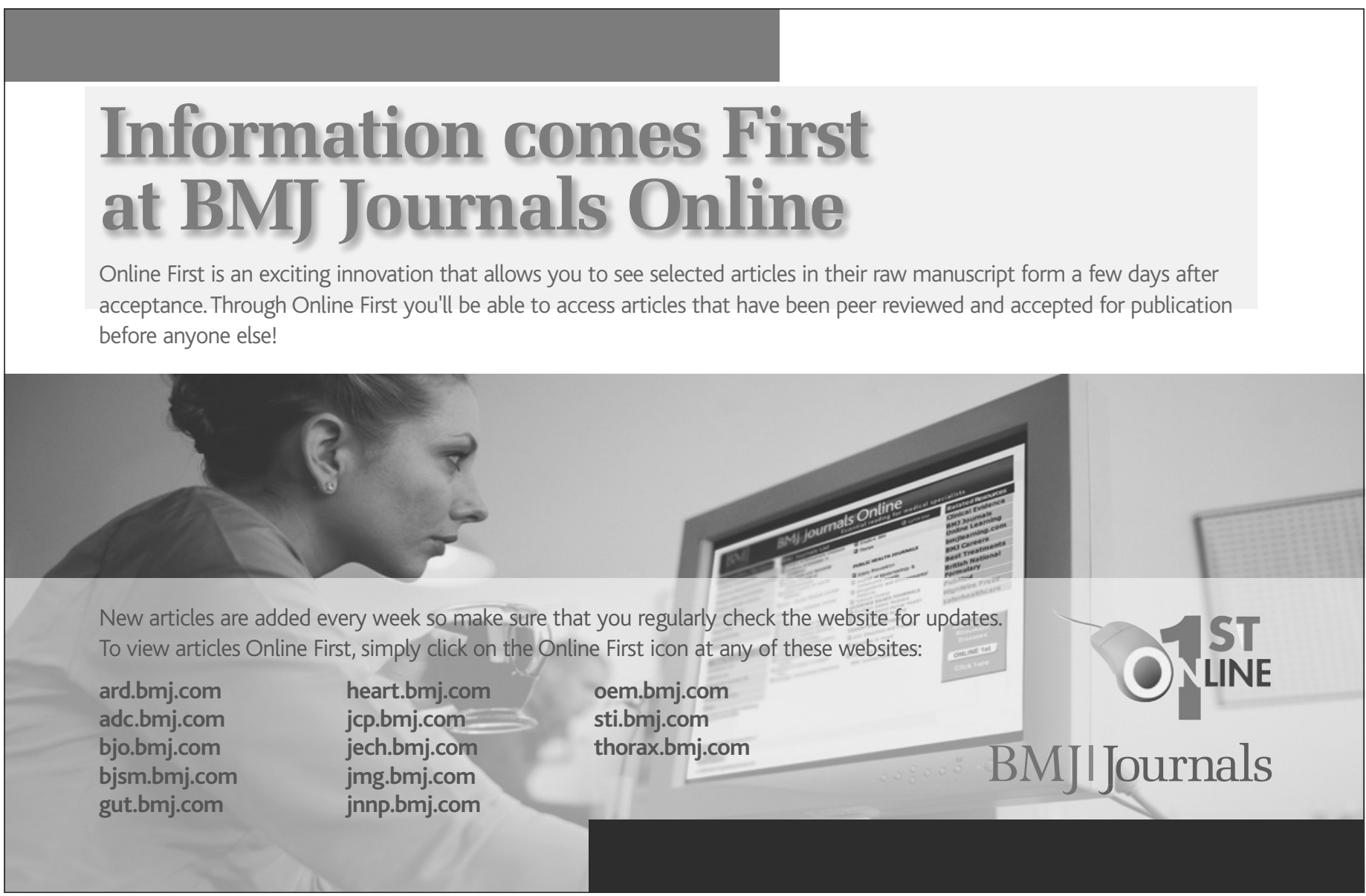

